\title{
ABSORPCJA ŚRODKÓW POMOCOWYCH PRZEZ LOKALNE SAMORZĄDY NA PRZYKŁADZIE WOJEWÓDZTWA KUJAWSKO-POMORSKIEGO (WYBRANE ASPEKTY)
}

\section{Streszczenie}

Przystąpienie Polski do Unii Europejskiej (UE) miało wymiar symboliczny, pojawiały się nawet określenia, że stanowiło zakończenie naszej transformacji ustrojowej. Spory w zakresie skutków akcesji Polski w struktury zjednoczonej Europy trwają dłużej, niż nasza w nich obecność. Wątpliwości, czy przyczyni się ona do gruntownej modernizacji Polski, czy też przysporzy przede wszystkim krótkookresowych korzyści, towarzyszą nie tylko licznym badaczom tych zagadnień, lecz również obywatelom, a więc największym beneficjentom wspólnotowych funduszy. Niniejsza praca stanowi przegląd wybranych poglądów w zakresie bilansu naszej obecności w UE ze szczególnym uwzględnieniem poglądów krytycznych.

Słowa kluczowe: absorpcja środków pomocowych; finanse samorządowe.

\begin{abstract}
Polish accession to the European Union (EU) had a symbolic dimension, appeared even determine that was the end of our transition. Disputes on the impact of Polish accession to the structure of a united Europe last longer than our presence in them. Doubts whether it will contribute to a thorough modernization of the Polish or will bring mostly short-term benefits, accompanied by not only numerous researchers of these issues, but also the citizens, and therefore the biggest beneficiaries of EU funds. This paper provides an overview of selected views on the balance of our presence in the EU with special emphasis on critical views.
\end{abstract}

Keywords: absorption of the EU funds; local governments funds. 


\section{Wstęp}

Przystąpienie Polski do Unii Europejskiej (UE) miało wymiar symboliczny, pojawiały się nawet określenia, że stanowiło swoiste zakończenie naszej transformacji ustrojowej ${ }^{1}$. Spory w zakresie skutków akcesji Polski w struktury zjednoczonej Europy trwają dłużej, niż nasza w nich obecność. Wątpliwości, czy przyczyni się ona do gruntownej modernizacji Polski, czy też przysporzy przede wszystkim krótkookresowych korzyści, towarzyszą nie tylko licznym badaczom tych zagadnień, lecz również obywatelom, a więc największym beneficjentom wspólnotowych funduszy.

Niniejsza praca stanowi przegląd wybranych poglądów w zakresie bilansu naszej obecności w UE ze szczególnym uwzględnieniem poglądów krytycznych jak też wybrane dane finansowe dotyczące gmin i powiatów $\mathrm{z}$ terenu województwa kujawsko-pomorskiego. Wybrany temat nie powinien w żadnym wypadku być odbierany jako wyraz sceptycyzmu autora, lecz bardziej troski o skuteczność gospodarowania wspólnymi dobrami oraz zintegrowany rozwój kraju jako całości, jak też poszczególnych regionów.

\section{Krytyczne opinie o absorpcji środków pomocowych}

Rozważania w zakresie skutków korzystania ze wspólnotowego wsparcia wymagają uwzględnienia wielu czynników. Niewątpliwie wielkość otrzymywanych transferów zasługuje na jednoznacznie pozytywną ocenę. Niestety nie musi się to przełożyć na trwały rozwój.

Wątpliwości pojawiają się już przy ocenie sposobu wykorzystania analizowanych środków ${ }^{2}$. Zdecydowana ich większość przeznaczana jest bowiem na inwestycje infrastrukturalne lub służące wyłącznie poprawie warunków życia mieszkańców. W ocenie T.G. Grosse oraz Ł. Hardta w zbyt małym stopniu służą one wzmacnianiu konkurencyjności i innowacyjności ${ }^{3}$ Przyjęty model modernizacji kraju jest w efekcie zbyt mocno egzogeniczny. W połączeniu z „pasywnością krajowych elit” odczuwa się wyraźny niedosyt.

Jak wskazuje G. Gorzelak nasze członkowstwo w UE buduje niestety również negatywne postawy społeczne. Wśród nich wymienia zanik myślenia

\footnotetext{
J. Górniak, S. Mazur (red.) Zarzadzanie strategiczne rozwojem, Warszawa 2012, s. 9.

http://www.sobieski.org.pl/unijna-pulapka (dostęp: 28.04 .2016 r.).

Tamże.
} 
strategicznego (o strategii myśli się jedynie pod kątem wydatkowania funduszy wspólnotowych) oraz przeświadczenie, że jedyną korzyścią z naszego członkowstwa w UE są te właśnie środki ${ }^{4}$.

Dotychczasowe doświadczenia wskazują również, że biedniejsze regiony rozwijają się wyraźnie wolniej, niż regiony wysoko rozwinięte, nawet pomimo wspólnotowego wsparcia ${ }^{5}$. Polaryzacja regionów pod względem społeczno-gospodarczym wydaje się być nieunikniona. Przeprowadzane cyklicznie przez G. Gorzelaka badania ankietowe wskazują, że dystans między liderami rozwoju oraz jego maruderami nie zmienia się w wyraźny sposób. Ciągle wyraźne są „,szwy rozbiorowe”, szczególnie widoczne w przypadku gmin Kongresówki, w odniesieniu do których zapóźnienia rozwojowe są niestety zjawiskiem trwałym i stabilnym ${ }^{6}$. Wyniki tych badań potwierdzają spostrzeżenia poczynione przez innych badaczy analizowanych zjawisk oraz potwierdzają ich obawy dotyczące skuteczności funduszy UE w zakresie spójności polskich regionów. W UE obserwowana jest co prawda konwergencja do przeciętnego poziomu PKB per capita, jej źródła są jednak efektem zasilania finansowego ze wspólnotowego budżetu?

Wśród polskich samorządów widoczny jest swoisty kult inwestowania w infrastrukturę społeczną, ogromne zapóźnienia i potrzeby stanowią uzasadnienie takiego stanu rzeczy. Zauważyć jednak należy, że w związku z przechodzeniem do cywilizacji informacyjnej maleje jej ranga a wzrasta znaczenie czynników społeczno-kulturowych. Jak słusznie wskazuje M. Słodowa-Hełpa czas na zbudowanie infrastruktury gospodarczej jest stosunkowo krótki (szczególnie przy posiadaniu środków finansowych). Zaniedbania w zakresie budowania infrastruktury społecznej kładą się balastem na rozwój całego pokolenia natomiast kształtowanie kapitału społecznego jest jeszcze trudniejsze $\mathrm{i}$ jest wręcz procesem historycznym ${ }^{8}$.

4 http://www.wspolnota.org.pl/aktualnosci/aktualnosc/grzegorz-gorzelak-peryferyjne-regiony-nigdy-nie-dogonia-metropolii (dostęp: 28.04.2016 r.).

5 Do takich samych wniosków dochodzą również inni badacze omawianych zagadnień zob. http://ec.europa.eu/polska/news/opinie/121010_fundusze_unijne_dla_polski_pl.htm (dostęp: 28.04.2016 r.).

6 G. Gorzelak, B. Jałowiecki, Koniunktura w Polsce lokalnej 2013, „Studia Regionalne i Lokalne" 2014, nr 4(58), s. 23-24.

7 M.G. Woźniak, Rozwój społeczno-ekonomiczny w III Rzeczypospolitej. Efekty. Defekty. Warunki integracji, „Nierówności Społeczne a Wzrost Gospodarczy” 2014, nr 3(39), s. 39.

8 M. Słodowa-Hełpa, Rozwój zintegrowany. Warunki, wymiary, wyzwania, Warszawa 2013, s. $190-191$. 
Ekonomia jest nauką społeczną, niemniej wymaga się od niej, słusznie zresztą, większej precyzji i konkretności odpowiedzi, w tym w szczególności w zakresie predykcji. Stąd też uzasadnione byłyby krytyczne uwagi, iż przedstawione powyżej, krytyczne uwagi powinny być formułowane znacznie wcześniej. Okazuje się, że były - m. in. wspomniana już M. Słodowa-Hełpa już na początku polskiej obecności w UE formułowała pytania w zakresie skuteczności realizacji głównych celów pomocy ze środków UE, w tym wzrostu konkurencyjności polskich regionów. Prowadzone analizy wskazywały, że wiele planowanych inwestycji oczywiście poprawi warunki życia mieszkańców, niemniej ma niewiele wspólnego ze wzrostem konkurencyjności. Zarzuty formułowane były nie tylko pod adresem beneficjentów (w tym samorządów), ale przede wszystkim rządu i Komisji Europejskiej ${ }^{9}$.

\section{Co należy zmienić?}

Problemem Polski po akcesji do UE jest szkodliwe mnożenie przez rząd i jego agendy odcinkowych strategii, będących przede wszystkim koncertem życzeń dostosowanym do europocentrycznej modernizacji zalecanej w dokumentach UE, zorientowanych na zagospodarowanie pochodzących ze wspólnotowych funduszy „niby darmowych finansów”" Znajdują się wśród nich także racjonalne priorytety, niemniej często środki są nieefektywnie wykorzystywane na rozproszone, nieproduktywne działania. Powinny zaś być one zorientowane na zintegrowany rozwój, tj. taki, który umożliwia zharmonizowane podnoszenie jakości życia we wszystkich wymiarach bytu jednostkowego i społecznego oraz respektującego odpowiedzialność wewnątrzpokoleniową i międzypokoleniową.

Niewątpliwie fundusze UE pomagają rozwijać działalność inwestycyjną, pogłębiać współpracę oraz podnosić i promować lokalne umiejętności oraz innowacje, nie można jednak na strumieniach tych środków budować

9 M. Słodowa-Hełpa, Możliwości absorpcji funduszy Unii Europejskiej przez polskie regiony, ,Ruch Prawniczy, Ekonomiczny i Socjologiczny” 2015, nr 1, s. 183-184.

10 M.G. Woźniak, O ćwierćwieczu polskiej transformacji. Refleksje inicjowane pytaniami dra hab. Marcina Wojtysiak-Kotlarskiego. Część II - lekcje na przyszłość, „Nierówności Społeczne a Wzrost Gospodarczy" 2015, nr 2(42), s. 21-23. 
strategii rozwojowych ${ }^{11}$. Dotychczasowe doświadczenia pokazują, że kierunki jego planowania uzależnione są od tych właśnie funduszy. Poważnym zagrożeniem jest stawianie na ilość pozyskanych funduszy (określane czasem jako „wyciskanie brukselki” lub „opium absorpcji”) oraz premiowanie liderów ich „przerobu”, efekty takiego myślenia mogą okazać się wręcz antyrozwojowe. Pytania jak sprawnie i szybko wydać te środki należy pilnie przeformułować na jak wydać je najefektywniej. „Latwe pieniądze” nie zawsze są czynnikiem rozwojowym, przestrogą niech będzie przykład największych beneficjentów polityki spójności, a więc Grecja, Irlandia i Portugalia ${ }^{12}$.

Potrzebne jest również wielopoziomowe zarządzanie innowacyjnością w oparciu o model podmiotowy, który powinien być zasadniczo inny niż model europejski - zbiurokratyzowany, postrzegający innowacyjność poprzez nakłady i niedoceniający w należyty sposób oddolnych sprężyn innowacyjności ${ }^{13}$. Od czasu akcesji polityka konwergencyjna ewoluuje co prawda w kierunku polityki prorozwojowej i proinwestycyjnej; są one jednak ciągle zdeterminowane dystrybucją wspólnotowych funduszy. Konsekwencją konwergencji będzie zaś ich stopniowe zanikanie. Jeśli Polska nie zorientuje się na upowszechnianie innowacyjności to naszej gospodarce zagrozi pułapka średniego rozwoju oraz utrwalanie się jego niespójności w wymiarze ekonomicznym, społecznym oraz przestrzennym ${ }^{14}$. Mając na względzie te zagrożenia konieczne jest zintegrowanie oraz uruchomienie wewnętrznych mechanizmów innowacyjnych i prorozwojowych na poziomie regionalnym i lokalnym ${ }^{15}$.

11 M. Słodowa-Hełpa, Wyzwania stojace przed polskim samorzadem lokalnym w perspektywie 2014-2020, „Studia Oeconomica Posnaniensia” 2013, nr 6, s. 54.

12 M. Słodowa-Hełpa, Rozwój zintegrowany. Warunki, wymiary, wyzwania, Warszawa 2013, s. 202.

13 M.G. Woźniak, Rozwój społeczno-ekonomiczny w III Rzeczypospolitej. Efekty. Defekty. Warunki integracji, „Nierówności Społeczne a Wzrost Gospodarczy” 2014, nr 3(39), s. 51.

14 Imperatyw spójności nieprzypadkowo tak bardzo jest akcentowany w strategii rozwojowej. Nierówności te mogą bowiem poważnie osłabić tendencje rozwojowe - zob. G.W. Kołodko, Społeczne i przestrzenne aspekty zróżnicowania dochodów we wspótczesnym świecie, „Nierówności Społeczne a Wzrost Gospodarczy” 2014, nr 3(39), s. 32.

15 M.G. Woźniak, O niektórych problemach wspótczesnego człowieka, ekonomii i systemów ekonomicznych w kontekście integracji procesów rozwojowych, „Nierówności Społeczne a Wzrost Gospodarczy" 2015, nr 1(41), s. 206. 
Elementem wymagającym zmiany wydają się być również postawy znacznej części samorządowców. Problemem polskich samorządów jest niewielki stopień ich samodzielności finansowej. Nie dziwi więc, że prawie wszystkie ankietowane gminy wskazują na potrzebę zwiększenia budżetów samorządowych. Nie mniej dziwi jednak, że tylko co trzecia z nich źródeł zwiększonych dochodów upatruje w podatkach lokalnych ${ }^{16}$. W świetle wyników tych badań stwierdzić można, że fundusze UE są właśnie tym, czego pragną samorządy - pieniądzem, którego nie trzeba zdobywać poprzez niepopularne decyzje zwiększające obciążenia lokalnych przedsiębiorców oraz, co gorsza, mieszkańców (a więc również wyborców). Wyniki tych badań nie napawają optymizmem.

\section{Absorpcja środków pomocowych przez gminy oraz powiaty województwa kujawsko-pomorskiego}

W tabelach 1 i 2 oraz na wykresach $1-8$ zaprezentowane zostały zbiorcze dane związane $\mathrm{z}$ absorpcją środków pochodzących z budżetu UE przez lokalne samorządy (tj. szczebla gminnego oraz powiatowego) z terenu województwa kujawsko-pomorskiego ${ }^{17}$. Dane prezentują wydatki wskazanych samorządów oraz ich zadłużenie w latach 2003-2015. Rok 2013 został uwzględniony jako swoisty bilans otwarcia do ponad dziesięcioletniego okresu członkostwa w strukturach zjednoczonej Europy. Wszystkie dane zostały zaprezentowane po wyeliminowaniu wpływu inflacji ${ }^{18}$.

Tabela 1. Wydatki gmin województwa kujawsko-pomorskiego w latach 2003-2015 po wyeliminowaniu wpływu inflacji (w tym wydatki z budżetu UE, wydatki majątkowe oraz wydatki ogółem) w milionach PLN.

\begin{tabular}{|c|c|c|c|}
\hline Lata & Wydatki z UE & Wydatki majątkowe & Wydatki ogółem \\
\hline 2003 & 67,41 & 541,28 & 4401,74 \\
\hline 2004 & 123,88 & 604,69 & 4733,36 \\
\hline 2005 & 229,67 & 828,70 & 5327,59 \\
\hline 2006 & 407,68 & 1201,72 & 6226,86 \\
\hline
\end{tabular}

16 G. Gorzelak, B. Jałowiecki, Koniunktura w Polsce lokalnej 2013, „Studia Regionalne i Lokalne" 2014, nr 4(58), s. 18-19.

17144 gminy (w tym 4 miasta na prawach powiatu) oraz 19 powiatów.

18 Dane dotyczące wielkości inflacji w poszczególnych latach pochodzą z Głównego Urzędu Statystycznego. 


\begin{tabular}{|l|l|l|l|}
\hline 2007 & 310,51 & 1180,24 & 6405,62 \\
\hline 2008 & 201,33 & 1458,64 & 6958,18 \\
\hline 2009 & 209,75 & 1465,67 & 7099,45 \\
\hline 2010 & 642,81 & 1730,91 & 7683,26 \\
\hline 2011 & 888,19 & 1789,52 & 7694,23 \\
\hline 2012 & 856,03 & 1660,62 & 7663,42 \\
\hline 2013 & 622,43 & 1450,08 & 7690,14 \\
\hline 2014 & 871,74 & 1668,45 & 8255,95 \\
\hline 2015 & 575,77 & 1459,68 & 8257,07 \\
\hline
\end{tabular}

Źródło: obliczenia własne na podstawie sprawozdawczości budżetowej gmin województwa kujawsko-pomorskiego.

Wykres 1. Wydatki gmin województwa kujawsko-pomorskiego w latach 2003-2015 po wyeliminowaniu wpływu inflacji ( $w$ tym wydatki z budżetu UE, wydatki majątkowe oraz wydatki ogółem) w milionach PLN.

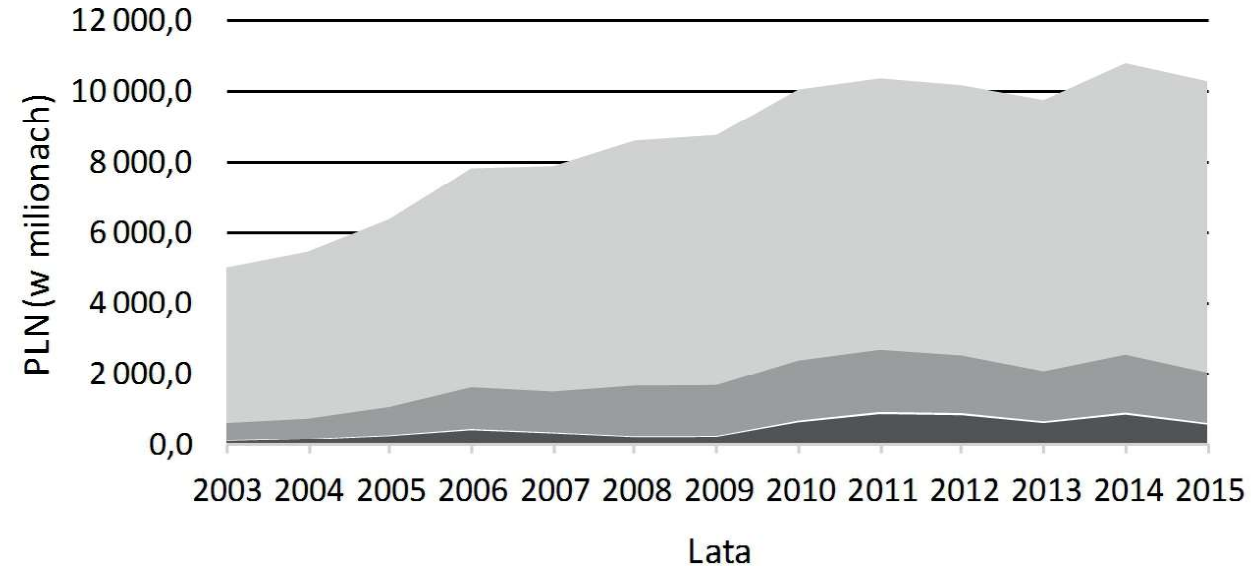

Wydatkiz UE Wydatki majątkowe Wydatki ogółem

Źródło: obliczenia własne na podstawie sprawozdawczości budżetowej gmin województwa kujawsko-pomorskiego. 
Wykres 2. Zadłużenie gmin województwa kujawsko-pomorskiego w latach 2003-2015 po wyeliminowaniu wpływu inflacji w milionach PLN.

\section{Zadłużenie}

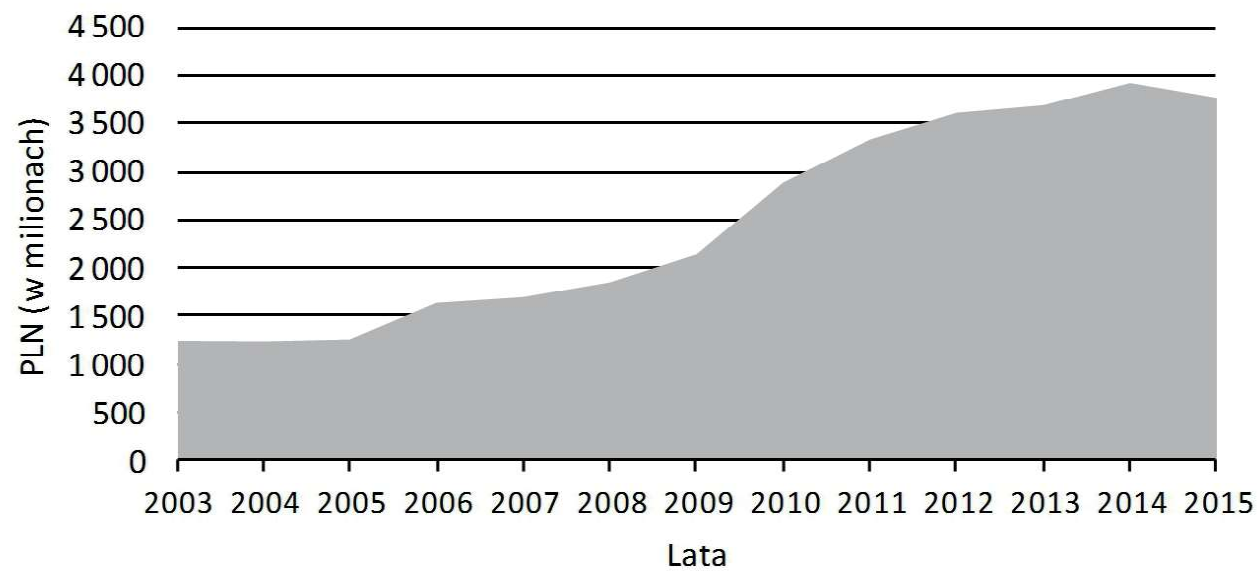

Źródło: obliczenia własne na podstawie sprawozdawczości budżetowej gmin województwa kujawsko-pomorskiego.

Wykres 3. Zadłużenie gmin województwa kujawsko-pomorskiego w latach 2003-2015 jako część zrealizowanych dochodów.

\section{Dług jako część dochodów}

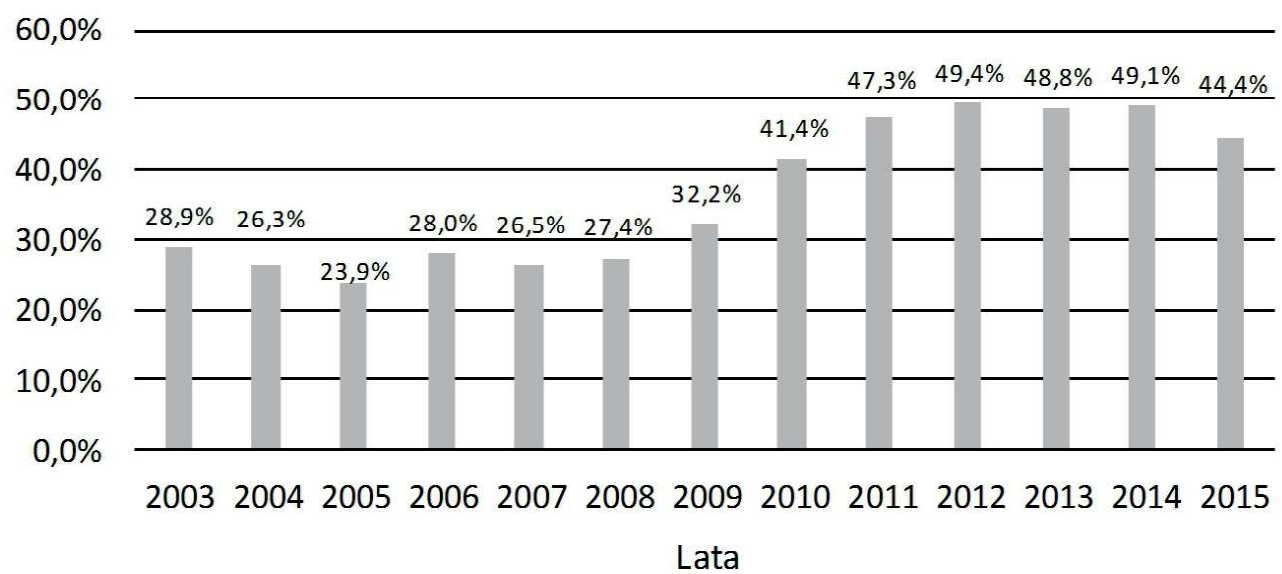

Źródło: obliczenia własne na podstawie sprawozdawczości budżetowej gmin województwa kujawsko-pomorskiego. 
Wykres 4. Zmiana poziomu zadłużenie a zaciągnięte zobowiązania zwrotne gmin województwa kujawsko-pomorskiego w latach 2003-2015 po wyeliminowaniu wpływu inflacji w milionach PLN.

\section{Zmiana długu a zaciągnięte zobowiązania}

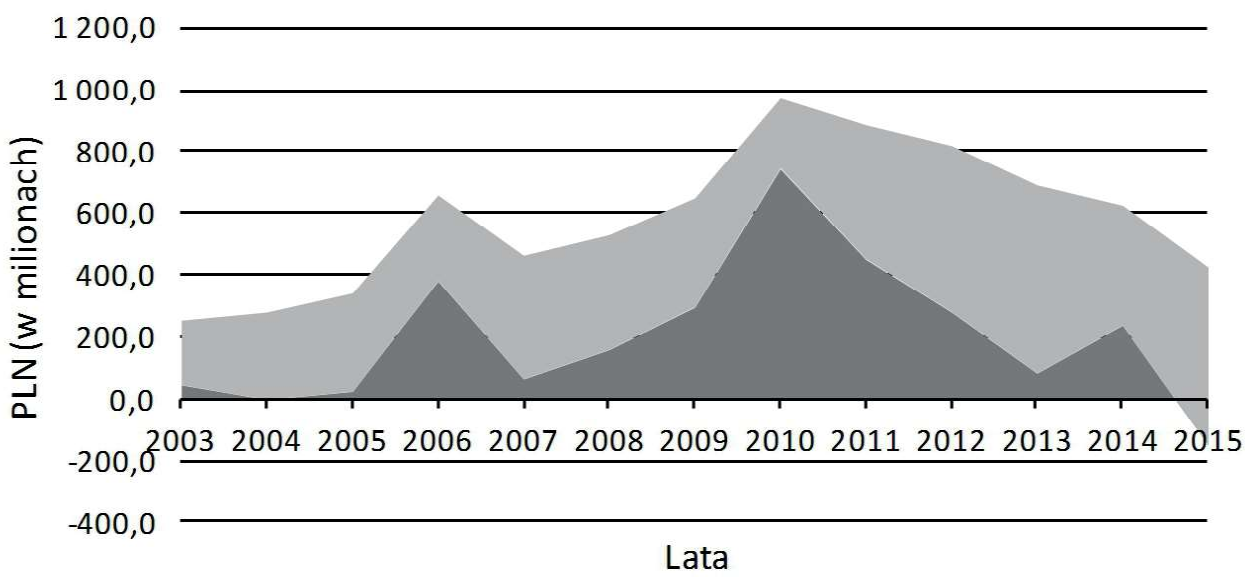

Źródło: obliczenia własne na podstawie sprawozdawczości budżetowej gmin województwa kujawsko-pomorskiego.

Tabela 2. Wydatki powiatów województwa kujawsko-pomorskiego w latach 2003-2015 po wyeliminowaniu wpływu inflacji (w tym wydatki z budżetu UE, wydatki majątkowe oraz wydatki ogółem) w milionach PLN.

\begin{tabular}{|c|c|c|c|}
\hline Lata & Wydatki z UE & Wydatki majątkowe & Wydatki ogółem \\
\hline 2003 & 5,1 & 41,9 & 723,45 \\
\hline 2004 & 21,5 & 54,1 & 753,75 \\
\hline 2005 & 52,7 & 72,0 & 838,35 \\
\hline 2006 & 69,5 & 100,0 & 941,30 \\
\hline 2007 & 35,9 & 76,8 & 906,62 \\
\hline 2008 & 10,2 & 99,5 & 991,92 \\
\hline 2009 & 84,8 & 247,8 & 1201,61 \\
\hline 2010 & 126,6 & 273,5 & 1322,03 \\
\hline 2011 & 96,6 & 209,7 & 1243,47 \\
\hline 2012 & 65,8 & 112,0 & 1123,11 \\
\hline 2013 & 68,9 & 135,3 & 1187,71 \\
\hline 2014 & 94,3 & 186,2 & 1242,12 \\
\hline 2015 & 67,8 & 164,4 & 1219,10 \\
\hline
\end{tabular}

Źródło: obliczenia własne na podstawie sprawozdawczości budżetowej gmin województwa kujawsko-pomorskiego. 
Wykres 5. Wydatki powiatów województwa kujawsko-pomorskiego w latach 2003-2015 po wyeliminowaniu wpływu inflacji (w tym wydatki z budżetu UE, wydatki majątkowe oraz wydatki ogółem) w milionach PLN.

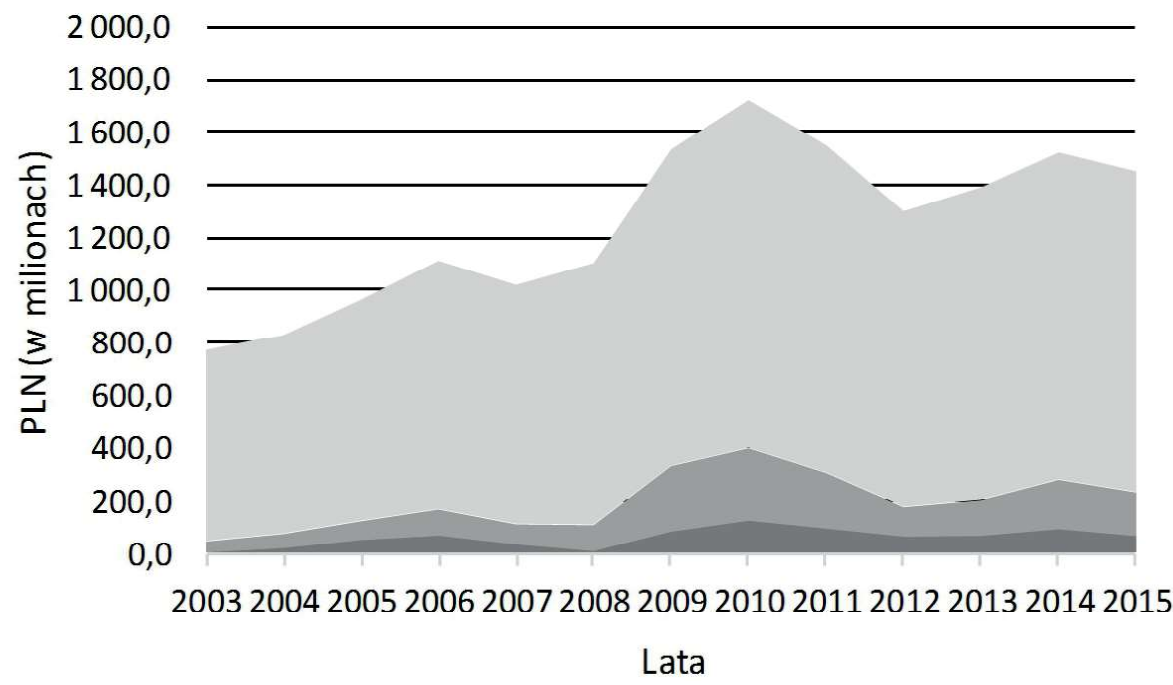

Wydatki z UE Wydatki majątkowe Wydatki ogółem

Źródło: obliczenia własne na podstawie sprawozdawczości budżetowej gmin województwa kujawsko-pomorskiego.

Wykres 6. Zadłużenie powiatów województwa kujawsko-pomorskiego w latach 2003-2015 po wyeliminowaniu wpływu inflacji w milionach PLN.

\section{Zadłużenie}

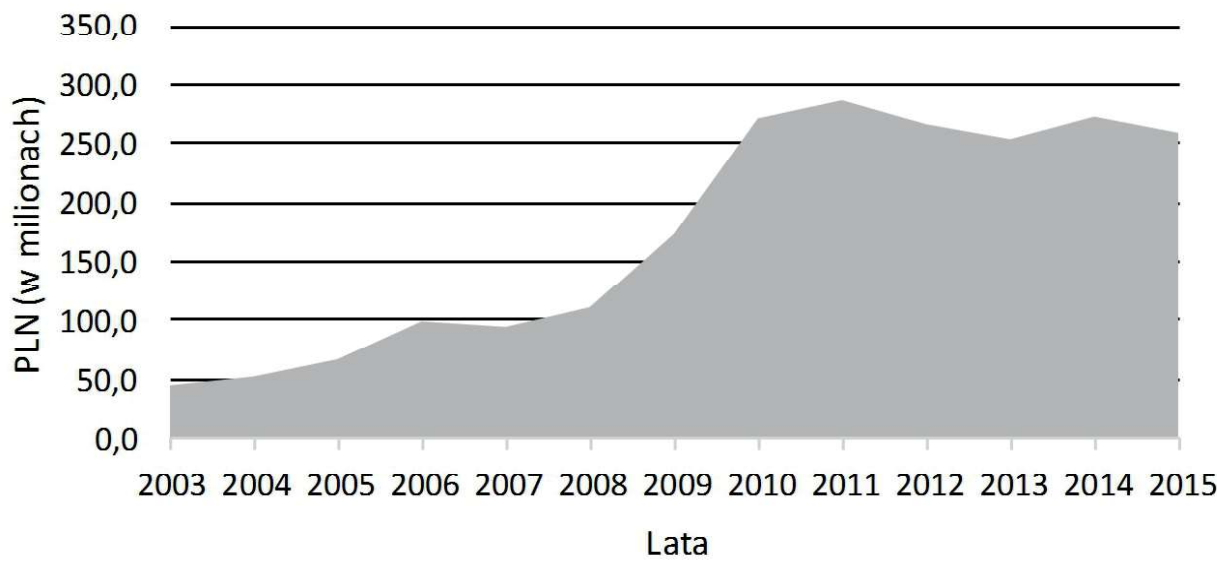

Źródło: obliczenia własne na podstawie sprawozdawczości budżetowej powiatów województwa kujawsko-pomorskiego. 
Wykres 7. Zadłużenie powiatów województwa kujawsko-pomorskiego w latach 2003-2015 jako część zrealizowanych dochodów.

\section{Dług jako część dochodów}

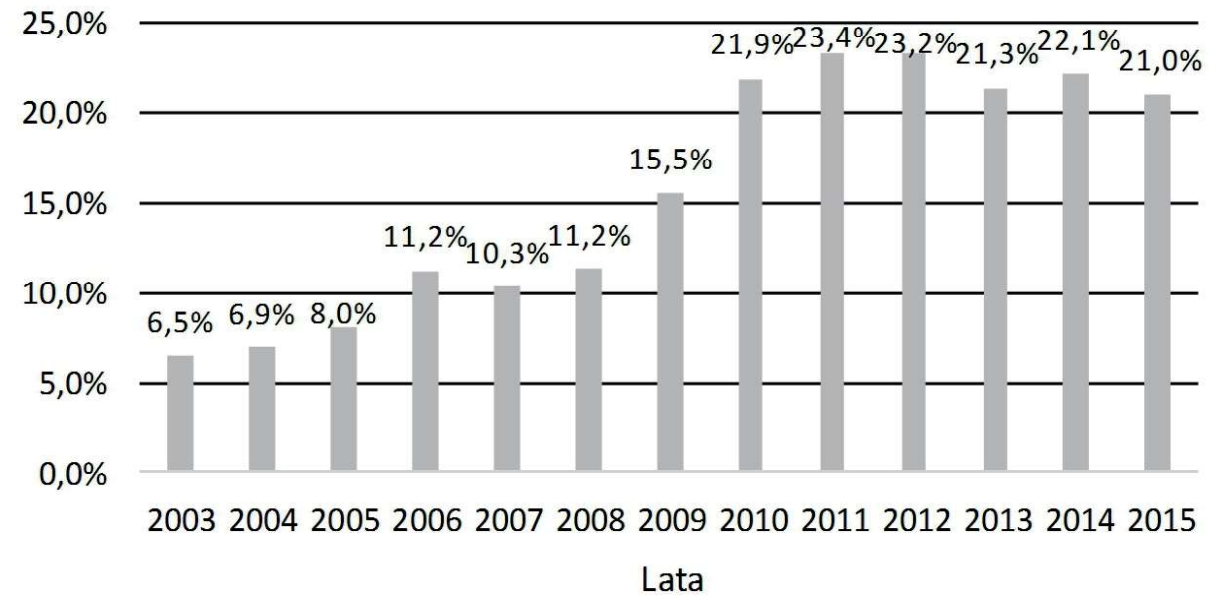

Źródło: obliczenia własne na podstawie sprawozdawczości budżetowej gmin województwa kujawsko-pomorskiego.

Wykres 8. Zmiana poziomu zadłużenie a zaciągnięte zobowiązania zwrotne powiatów województwa kujawsko-pomorskiego w latach 2003-2015 po wyeliminowaniu wpływu inflacji w milionach PLN.

\section{Zmiana długu a zaciągnięte zobowiązania}

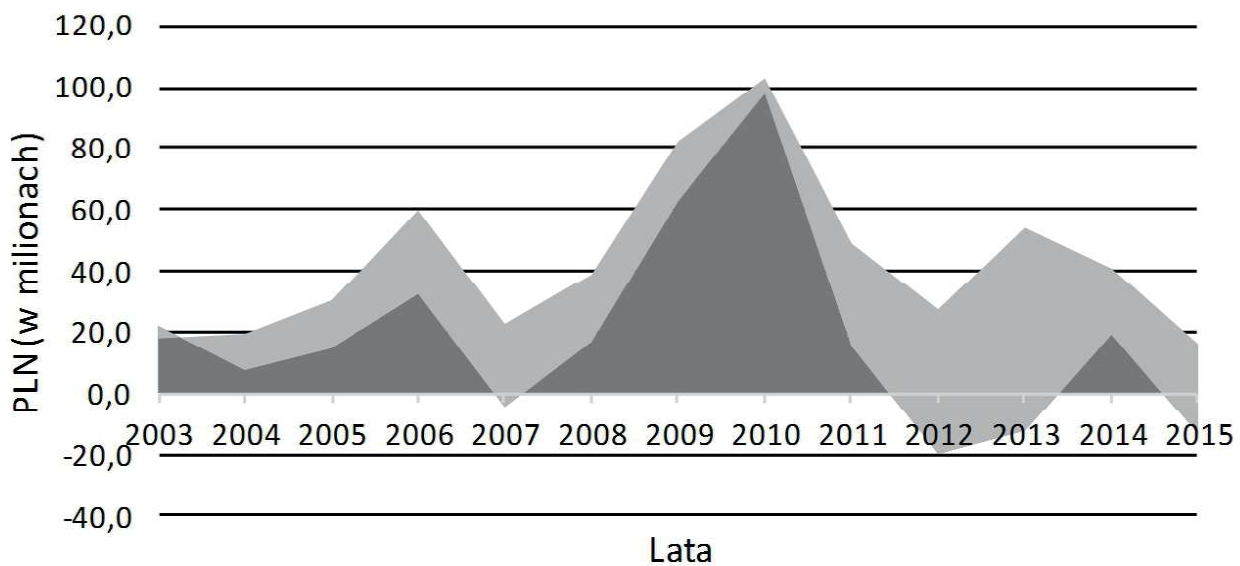

Źródło: obliczenia własne na podstawie sprawozdawczości budżetowej gmin województwa kujawsko-pomorskiego. 
Zgodnie $\mathrm{z}$ danymi zawartymi w sprawozdawczości analizowanych gmin wydatkowały one w okresie od 2003 do 2015 roku ponad 88 miliardów złotych, z tego 6 miliardów stanowiły wydatki ze środków pochodzących z funduszy pomocowych. W tym czasie powiaty wydatkowały 13,7 miliardów złotych, $\mathrm{z}$ tego blisko 800 milionów ze środków pochodzących z funduszy UE. Pokazuje to, jak znacznymi środkami publicznymi dysponują polskie samorządy lokalne a jednocześnie jak stosunkowo niewielka ich część przeznaczana jest bezpośrednio na zadania służące szeroko pojętemu rozwojowi. Zaprezentowane dane pokazują równocześnie, że znaczny wysiłek inwestycyjny samorządów wiązał się ze znacznym wzrostem ich zadłużenia. Najbardziej niepokojącym zjawiskiem jest lekceważone przez wielu badaczy zjawisko zaciągania długu na spłatę zobowiązań już istniejących - a więc tzw. rolowanie długu. Skala zjawiska przedstawiona została na wykresach 4 oraz 8 . Rolowanie długu przez samorządy województwa kujawsko-pomorskiego nie ma charakteru incydentalnego, a jest raczej zjawiskiem masowym. Stwierdzić należy, że działanie takie jest zgodne z prawem, niemniej zadłużenie to musi zostać kiedyś spłacone, co bez wątpienia w pewnym momencie stanie się barierą dla dalszego kreowania rozwoju lokalnego.

\section{Zakończenie}

Efekt cywilizacyjny funduszy UE dla kraju jest bezsprzeczny - ludziom żyje się lepiej, wygodniej i bezpieczniej. Samorządy terytorialne stały się dzięki środkom UE największym inwestorem publicznym. Powstała w wyniku samorządowych inwestycji infrastruktura służy przede wszystkim wytwarzaniu dóbr oraz świadczeniu usług zaspokajających potrzeby społeczności lokalnych. Jak słusznie zauważa B. Filipiak inwestycje to także potencjalne nowe miejsca pracy powstałe dzięki realizacji przedsięwzięć ${ }^{19}$. Inwestycje samorządowe stanowią także bardzo ważną determinantę wzrostu gospodarczego kraju. Wydatki te w okresie 2007-2012 przekraczały w każdym roku 50\% wydatków inwestycyjnych całego sektora publicznego ${ }^{20}$. Jeżeli jednak realizowane inwestycje nie

19 B. Filipiak, Przesłanki dokonania oceny samorzadowego dtugu publicznego na tle podejścia badawczego, [w:] E. Denek, M. Dylewski (red.), Szacowanie poziomu zadtużenia jednostek samorzadu terytorialnego $w$ warunkach zwiększonego ryzyka utraty plynności finansowej, Warszawa 2013, s. 190.

20 K.S. Cichocki, Zarzadzanie finansami i dtugiem samorzadu terytorialnego w perspektywie wieloletniej, Warszawa 2013, s. 15. 
zostaną wykorzystane do kreowania dalszego rozwoju to, jak słusznie wskazuje J. Czempas, mogą stać się balastem i zamiast zysków dla społeczności lokalnych przyniosą przede wszystkim straty ${ }^{21}$. Znaczny wysiłek inwestycyjny polskich samorządów możliwy dzięki środkom ze wspólnotowego budżetu połączony był ze znacznym wzrostem zadłużenia. Problem jego spłaty jest jak dotąd skutecznie odraczany. Nie należy oczekiwać, aby ten stan rzeczy uległ zasadniczej zmianie w najbliższych latach. Priorytetem wielu samorządów jest bowiem absorpcja kolejnych środków ze wspólnotowego budżetu. Ważne jest, aby środki te zostały w sposób przemyślany wydatkowane.

Historia pokazuje, że instytucje sprawdzone w innych miejscu i czasie nie zawsze są najlepszym rozwiązaniem dla wszystkich regionów i krajów. Wzorowanie się Polski na rozwiązaniach Zachodnioeuropejskich, obarczonych wysokimi kosztami transakcyjnymi, nie musi być najlepszym wyborem. Ciągle zasadne i aktualne jest więc sformułowane przez J. Szomburg pytanie jak przegonić Zachód nie doganiając go?22

\section{Literatura}

1. Cichocki K.S., Zarzadzanie finansami i dtugiem samorzadu terytorialnego w perspektywie wieloletniej, Polska Akademia Nauk Instytut Badań Naukowych, Warszawa 2013.

2. Czempas J., Skłonność jednostek samorzadu terytorialnego do inwestowania. Ujęcie ilościowe na przykładzie miast na prawach powiatu województwa śląskiego, Wydawnictwo Uniwersytetu Ekonomicznego w Katowicach, Katowice 2013.

3. Filipiak B., Przesłanki dokonania oceny samorzadowego dtugu publicznego na tle podejścia badawczego, [w:] E. Denek, M. Dylewski (red.), Szacowanie poziomu zadtużenia jednostek samorządu terytorialnego w warunkach zwiększonego ryzyka utraty plynności finansowej, Difin, Warszawa 2013.

4. Gorzelak G., Jałowiecki B., Koniunktura w Polsce lokalnej 2013, „Studia Regionalne i Lokalne" 2014, nr 4(58), s. 5-24.

5. Górniak J., Mazur S. (red.), Zarzqdzanie strategiczne rozwojem, Ministerstwo Rozwoju Regionalnego, Warszawa 2012.

6. Kołodko G.W., Spoleczne i przestrzenne aspekty zróżnicowania dochodów we wspólczesnym świecie, „Nierówności Społeczne a Wzrost Gospodarczy” 2014, nr 3(39) s. 26-37.

7. Słodowa-Hełpa M., Możliwości absorpcji funduszy Unii Europejskiej przez polskie regiony, „Ruch Prawniczy, Ekonomiczny i Socjologiczny” 2015, nr 1, s. 167-185.

21 J. Czempas, Skłonność jednostek samorzadu terytorialnego do inwestowania. Ujęcie ilościowe na przykładzie miast na prawach powiatu województwa śląskiego, 2013, s. 11.

22 M. Słodowa-Hełpa, Rozwój zintegrowany. Warunki, wymiary, wyzwania, Warszawa 2013, s. 195-196. 
8. Słodowa-Hełpa M., Rozwój zintegrowany. Warunki, wymiary, wyzwania, CeDeWu, Warszawa 2013.

9. Słodowa-Hełpa M., Wyzwania stojace przed polskim samorządem lokalnym w perspektywie 2014-2020, „Studia Oeconomica Posnaniensia” 2013, nr 6, s. 32-57.

10. Woźniak M.G., O ćwierćwieczu polskiej transformacji. Refleksje inicjowane pytaniami dra hab. Marcina Wojtysiak-Kotlarskiego. Część II - lekcje na przyszłość, „Nierówności Społeczne a Wzrost Gospodarczy" 2015, nr 2(42), s. 7-25.

11. Woźniak M.G., O niektórych problemach współczesnego człowieka, ekonomii i systemów ekonomicznych w kontekście integracji procesów rozwojowych, „Nierówności Społeczne a Wzrost Gospodarczy" 2015, nr 1(41) s. 195-213.

12. Woźniak M.G., Rozwój społeczno-ekonomiczny w III Rzeczypospolitej. Efekty. Defekty. Warunki integracji, „Nierówności Społeczne a Wzrost Gospodarczy” 2014, nr 3(39), s. 38-54.

Daniel Jurewicz

Regionalna Izba Obrachunkowa w Bydgoszczy 